\title{
THE BULGARIAN VILLAGE: SUSTAINABILITY IN TRANSFORMATION MODE
}

Not everything that could be evaluated is essential
and not everything essential could be evaluated. Albert Einstein

\begin{abstract}
The paper attempts to raise certain questions, the answers to which are probably the emanation of the Bulgarian village. What is the reason for its sustainability, manifested and outlined particularly in the transformation periods? In the periods of crisis the village is a social buffer of the society. The sustainability of the village is outlined in the report through a series of indicators.

The roots of this process can be tracked in the three-unit chain: man-nature-society. The contemporary rural community upgrades the etymological definition, identifying the village as a settlement whose population is engaged in agriculture. In support of the village sustainability thesis, the report undertakes to reveal the significance of the changes in CAP and its greening. The man and his habitat are among the priorities of the $21^{\text {st }}$ century.
\end{abstract}

Keywords: village, sustainability, transformation, CAP 2014+.

JEL codes: Q00, Q01, Q15.

\section{Introduction}

The village is a basic unit in all stages of the Bulgarian economic history. The issue of the villages is well known, continuously explored and analysed in details. Probably some Bulgarian citizens consider functions of the villages declining, and their role and importance decreasing, but for the researchers, the problems related to the village, to rural communities and to agricultural production will form new analytic fields in the future. 


\section{Traditions and restart}

The "restart" of the primary sector has been initiated. The discovery of deep layers in the chain man - nature - society and their incorporation in the Common European policy presumes new expertise and its superposition on the traditional environment-friendly practices of the Bulgarian producers. The future of agriculture and its sustainable incorporation in the social model of the community, depends on the rediscovery of its significance and on the answer to the question: Why is it a traditional sector for the country? It is not only a matter of its strong positive impact on the national economy. The primary sector has not lost and will not lose its significance, due to one essential reason that is existential, namely, agriculture creates vital food products for the population subsistence and healthy livelihood. In spite of the decreasing share of the village in the creation of value and employment and in spite of production expansion of the so-called industrial foods and the wide range of synthetic enhancers and flavours, the taste of fresh food does not need any "spicing". The organoleptic qualities, the vitamins, minerals and amino acids in the composition of the "born on root" production are based on the principles of environment-friendly and healthy nutrition. This is the reason for the essential imprint of the village on the national psychological profile of Bulgarian population into the distant and recent past. This imprint nourishes the next generations with sustainable love to the land. The roots are deep, like the vital forces of the nutrient environment, the challenges of the present days lead inevitably to the restart of agriculture. Because not everything essential could be measured, as Einstein said, a part of paradigms of the recent past - profitability, competitiveness and profit on the free market, are nowadays increasingly dominated by greening and implementation of other methods for attenuation of negative impacts of the human economic activity on the living environment. Nature is a constant participant of the production process in the primary sector and the starting point for this production. The economic results and the vitality of economic units depend on the quality of natural resources. Therefore sustainable natural environment is necessary for sustainable results. Agriculture is a part of this environment. The village and agriculture have sustainable and continuing significance, especially in periods of institutional changes and transformations. The institutional culture in Bulgarian village in the last decades has proved repeatedly its creativity and it is a guarantee for the restart of agriculture in the country. Traditions and prospects of the sector development have a potential for the realization of essential synergic effects.

\section{Economic situation and institutional environment}

Changes in the economic situation and institutional environment at different periods of the country's development have a direct impact on the village and on the agriculture, and vice versa. The village is a source of vital impulses in 
case of unfavourable political and economic changes. This is the genesis of its sustainability. The process of sustainability for agriculture has been manifested in the regime of transformation of the socio-political and economic system. For all institutional changes, undertaken in different periods of the economic and political history of the country, the village has a positive role for the socio-economic relations. It neutralizes the negative impact of some political and economic decisions having institutionally unfavourable results on the economic environment. The village possesses its own institutional culture, which plays the role of a social buffer for the cases of the created economically unbacked institutional environment. Especially for some complex institutional changes of the last decades, the village and agriculture fulfilled a constructive role in ensuring occupation, creating opportunities for the economic activity revival in respective regions or in the national economy as a whole. How to overcome the institutional change? Douglas North, Nobel laureate from 1993, in his lectures and work Institutions, institutional change and economic results examines this theme. The author writes: "institutions are the game's rules in a society or the restrictions, imposed by humans forming the human relations" (North, 2000, p. 12). He continues by stating that: "Institutions are sets of formal rules, informal restrictions and mechanisms for their forced keeping. It is important that the formal rules could be changed by the state and informal rules change very slow" (North, 2004, pp. 1-2). The rules include two levels: (1) formal, which change easily and form the organisational structure; and (2) informal, consisting of "established practice, traditions, culture - these are things defining the stability of informal rules." (North, 2004, p. 3). The differentiation of the two levels establishes a framework for the opportunities, for their coincidence or divergence. Sometimes the formal and informal rules do not coincide. "At a sharp change of rules it could appear that they are foreign to the institutional culture and as a result, there occurs a collision within the institution itself, between rules and institutional culture" (Kabakchieva, 2007, p. 128).

The roots of informal rules of institutional culture of the village lead to the eternal traditions for development of agriculture and livestock breeding in Bulgaria. The strong relation between the agricultural producer and the agricultural labour is predetermined by the extremely favourable monopolistic natural advantages of Bulgaria. The four separate seasons in the natural calendar are a precondition for the growing of 145 cultural kinds of crops in a free environment in the open air. The agro-ecologic prerequisites are the basis of every analysis of the potential, the role and the importance of agriculture in Bulgaria. The combination of natural and climatic phenomenon, constituting the existing agro-climatic zones and the richness of fertile soil types in the country, is the starting point for the strong presence of the primary sector in the material production and its major impact on economic results in the sector. The significance of the primary sector for the national economy and for the socio-economic 
environment of the country comes natural. The rich and varied natural resources extremely abundant as a potential for agricultural production, are the source of the phenomenon of the rural sustainability and the devotion of the rural residents to the land.

Many changes in economic history have a direct impact on the village. The dynamics in the political and economic environment and their accompanying institutional changes, receive systematic responses from the village and agriculture. Several examples of institutional changes in the sector, reveal the sustainability of the village and the significance of the agriculture in the establishment of better social parameters and higher economic performances in the rural areas and in the whole society.

\section{Reform in production structures - new institutional environment}

The first example, indicated in the case of a change in institutional environment, is related to the change in the existing agricultural organizations functioning as socio-economic systems. The transformation of Labour Agricultural Cooperatives into Agricultural Production Cooperatives in 1975 separated those employed in agriculture from taking direct care of the ancestral land properties. The production consolidation was carried out under the political orders and it was accompanied by major institutional changes. The result is that:

"the rural people were deprived of the opportunity to manage. They lost interest in farms, because it became impossible for them to exercise any real influence, (...) the life conditions pushed them to the lowest steps of social self-confidence. (...) The farms under the Agricultural Production Cooperatives have been conquered by the bureaucratic machinery. (...) The role of producers was to execute uncomplainingly the will of someone else."

(Stankov, 1990, p. 31).

The aim of the socialization of production structures was to meet the party theses, valid in the period of 1980 s, for equalization of the mental and the physical labour. The village had not been omitted in this case. The industrialization had started. Some productions of field crops had initialized its start. This was reported as a success, despite the retardation of some important structure-defining sectors of crop growing, having comparative advantages for Bulgaria, such as the fruit growing. The institutional reform did not meet sustainable crop models in Bulgarian village, which were built and implemented by generations of farmers. The reaction was predetermined and predictable.

The answer of cooperated villagers to the institutional formal rules / norms is presented graphically on Figure 1. After 1975, the auxiliary farms sharply increased their relative share in the produced national income. "This increase expresses the attitude of agricultural producers to agro-industrial complexes" (Iliev, 2004, p. 63). Analyses of other researchers are similar: "the saving role of the private farm has been born at the light of unsuccessful existence of the 
Agro-Industrial complexes and the structures afterwards. The created atmosphere decreased the popularity of the idea to search a solution in Labour Cooperative Farms and to support the creation of private farms" (Stankov, 1990, p. 32). Other authors search for the reason of agricultural crisis on the macro-level: "Our society has extorted agriculture from its natural and social roots and has put it in the 'alchemic retort' [according to the definition of Marx - alchemic retort of capital, note of the author] of the industrialization (conceived as violent and inadequate form of technologicalization and socialization)" (Pamukchiev, 1991, p. 10). The crisis predictability had high degree of authenticity. There were several reasons for non-realization of the above-mentioned. The scientific expertise had not been searched. There was a traditional sustainable practice for institutional changes and transformations to be realized in imperative way, with political motives and durable absence of economic arguments. In these situations the attitude of "informal restrictions", as called by North, and their oppositional attitude toward the formal rules is logical and symptomatic. Auxiliary farms of cooperated villagers are examples of sustainability in transformation regime.

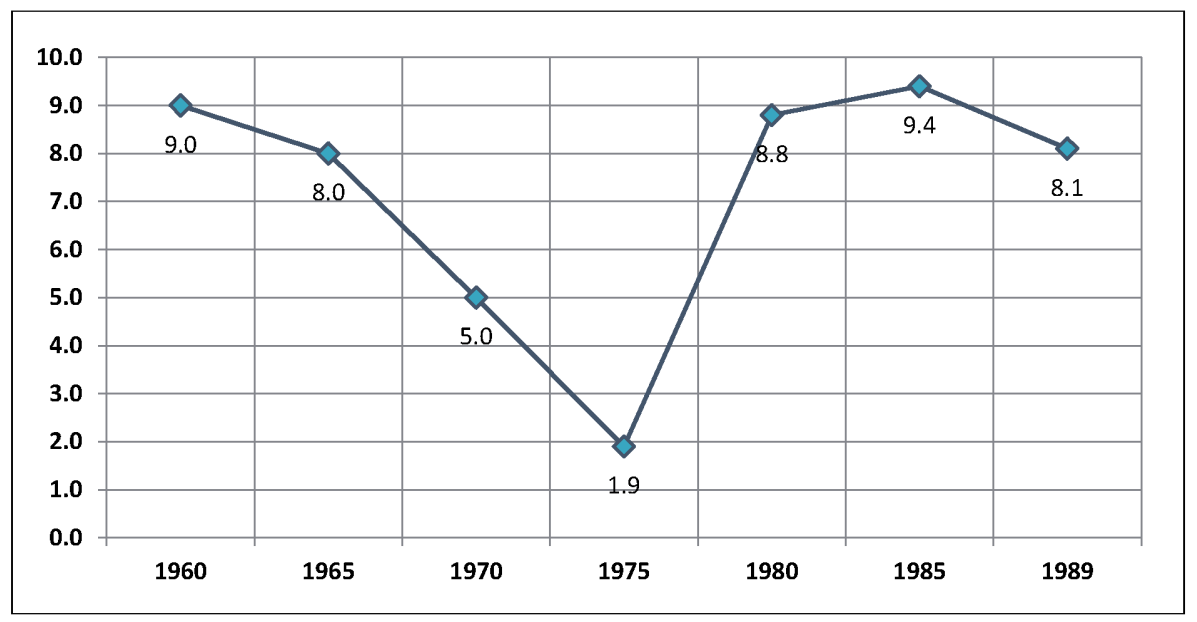

Fig. 1. Produced national income of auxiliary farms of cooperated rural inhabitants (\%). Source: data based on a research by $\operatorname{Iliev}(2001$, p. 62).

\section{Transformation in the socio-economic system}

The political and economic structure of the social model in Bulgaria has underwent a serious transformation. Under the ongoing transformation the village and agriculture kept their sustainability. This is the second example of sustainability. Institutional rules have changed cardinally. The transformation in Bulgaria consists in liquidation of all structures created and functioning under 
the centrally-managed farm. The result of the transformation is a direct result of the choice of the model for conversion of the political and economic system. The countries of Central Europe have chosen the social way of democratization of the society. Bulgaria accepted the liberal way of transformation and building of democratic structures. The institutions were new. Mechanisms for their forced compliance were created. In the changed environment the institutional culture also had its oppositional behaviour. This fact is expressed by the following macroeconomic manifestations:

- Prevalence of the gross value added created in the agricultural sector to the one created in the industry:

1996 - South-East region;

1997 - North-West, North Central, North-East, South-East;

1998 - North-East;

1999 - North-East.

- Prevalence of the gross value added created in the agricultural sector to the newly created value in the service sector:

1997 - North-East, and

1997 - South-East region.

These macroeconomic results, expressed in the gross value added structure, confirm "the significance of agricultural production in the period of transformation and transition to the market economy." It is indicative that in certain years and in some regions the agricultural sector generates even more of newly created value than the tourism sector. In the North-East and South-East regions there are the areas of Black Sea tourism concentration, which gives reason to go further in the analysis and detailed research on causes for the prevalence of value creation in the agricultural sector, especially in these regions. Two main factors have led to this positive economic fact. Active influence of the increased share of the newly created value and its predomination over other spheres of economic activity has a larger share of people employed in agricultural sector in these regions. In the 1990s crisis period, agriculture acted as a social buffer. A large part of working age people went out of the labour market and started to pursue agricultural activity. Agricultural production ensured employment for these people and their families.

Institutional culture, as a "historically formed public (or group) values, norms and practices" (Kabakchieva, 2007, p. 128) is a factor for sustainable behaviour of Bulgarian village and the source of sustainability for the behaviour of actors in Bulgarian agriculture in the period of major changes of state and functioning of the institution. The transformation of the social model in our country has created a crisis situation for Bulgarian citizens. A big part of them has found employment in the primary sector, which became a social buffer. This sector has proved its sustainable role in the national economy in the periods of transition, crises and society transformation. 


\section{The EU-27 accession of Bulgaria}

Bulgaria is a full member of the common European Economic Area as of 2007. This is a third example to highlight the sustainability of agriculture within a new institutional framework. The act of full European membership put serious challenges on the national economy. The negative trade balance characterizes the strongly open nature of our economy and is accompanied by a loss of national income. This leads to costs and to an outflow of an increasingly large part of the GDP out of the country. Figure 2 presents information on the foreign trade flows from and to Bulgaria. It could be noticed that all the period of preparation and full membership of the country in the EU-27 has been characterised by negative foreign trade balance. The trend becomes stronger in the years after 2007. Other characteristic of the foreign trade is that foreign trade flows of agricultural goods have positive foreign trade balance. Contrary to the total trade, the trade in agricultural goods realizes incomes. This fact is of vast importance, proving sustainability of the sector. Institutional change of 2007 in both agriculture and all the country had no analogue in the past. The sector suffered from serious structural misbalances. The relative share of crop growing increased sharply on the account of the livestock breeding. Structural changes occurred in the crop growing. The positive balance of the agricultural trade is due, predominantly, to the exportation of cereals. This is a result of the withdrawal of the state from the sector and of the big reduction of the support for the agricultural production. Despite the drop in the sector of fruit and vegetables, the growth for the cereals is significant. The reason for this phenomenon is the chosen way of support for farmers in Bulgaria. The system of single area payment is easy to administrate, which probably was the leading argument for its choice. Beneficiaries growing field crops have profited from this choice of bureaucrats.

The above-mentioned are mostly large-size producers of cereals. Supported by pre-accession funds and CAP resources, the profits of this production are substantial. Other economic advantages for these producers are the secure and constantly enlarging markets. Namely, the increasing exportation of cereals contributed even though to a symbolic decrease in the negative foreign trade balance. The institutional environment used as rules and mechanisms for keeping a positive impact on the sector and on the national economy.

There is a strong bipolarity on the structural and sector levels. The detailed analysis reveals problems with the institutional framework, the overcoming of which would contribute to the development of the sectors, which produce under monopolistic conditions. Their present situation is completely dominated by the cereals. In this area, there is a problem of the society (socium), which is not the subject of the present analysis, so we will not go in details. However, we would like to mention the increasing trend of fiscal frauds in the trade in cereals registered by the National Revenue Agency. 


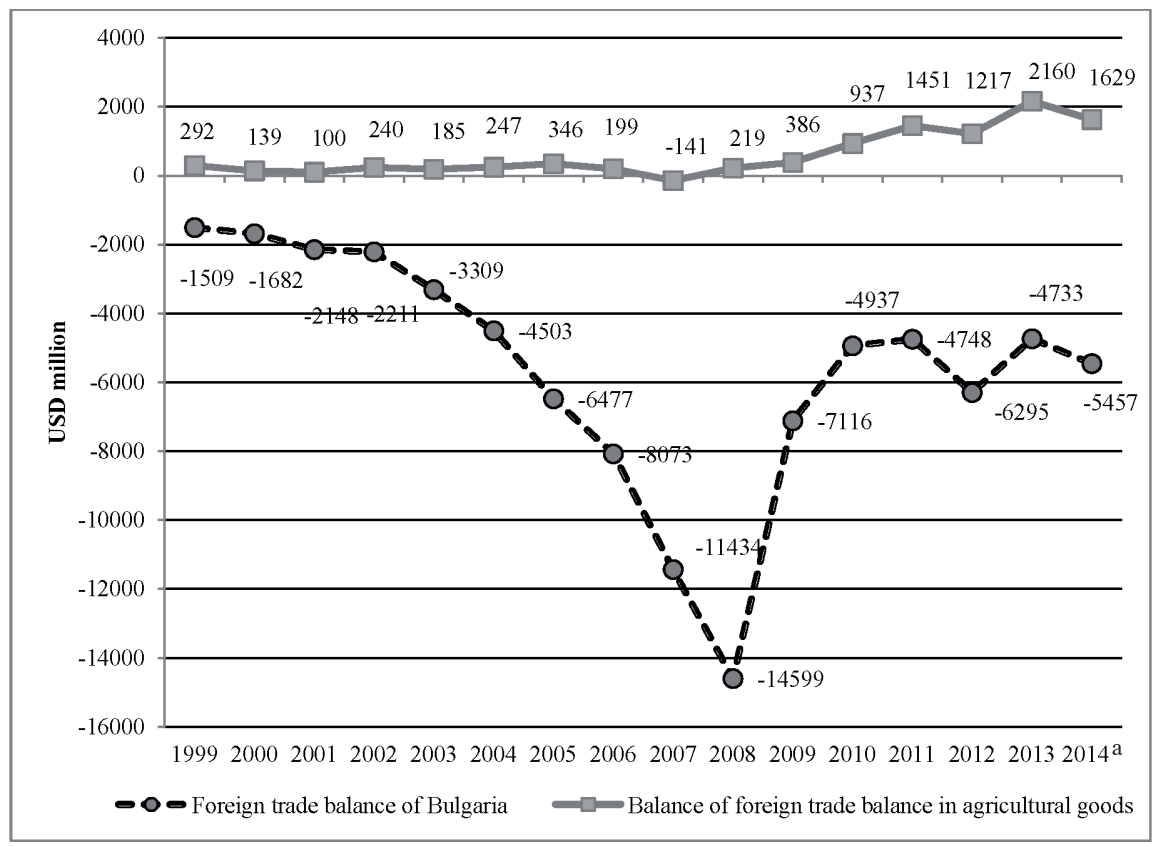

a 2014 - preliminary data

Fig. 2. Foreign trade of Bulgaria (USD million).

Source: Ministersvo na zemedelieto i hranite. Agrarni dokladi 2000-2015, data of the National Statistical Institute, Agency "Customs".

\section{Opportunities for sustainability maintenance}

Considerable opportunities for sustainable production are characteristic for the future of Bulgarian village and the primary sector. We will illustrate this judgment by the following available, but not used enough, reserves in this direction: enlargement of the utilized agricultural area (UAA) for organic agriculture and for NATURA 2000, increasing of livestock density index. There are also other opportunities, which also have a high potential for maintaining the sustainable development. They will be mentioned and broadly analysed in subsequent texts.

Figure 3 reveals huge natural opportunities for organic production in Bulgaria. The natural environment is Bulgaria is clean and protected. Bearing in mind the enlarging niche market in the world, in the Old Continent and already in Bulgaria, the perspectives for sector's sustainable development are optimistic. The institutional norm of the European policy is in harmony with the institutional culture, which is also a reason for organic production sustainability. 


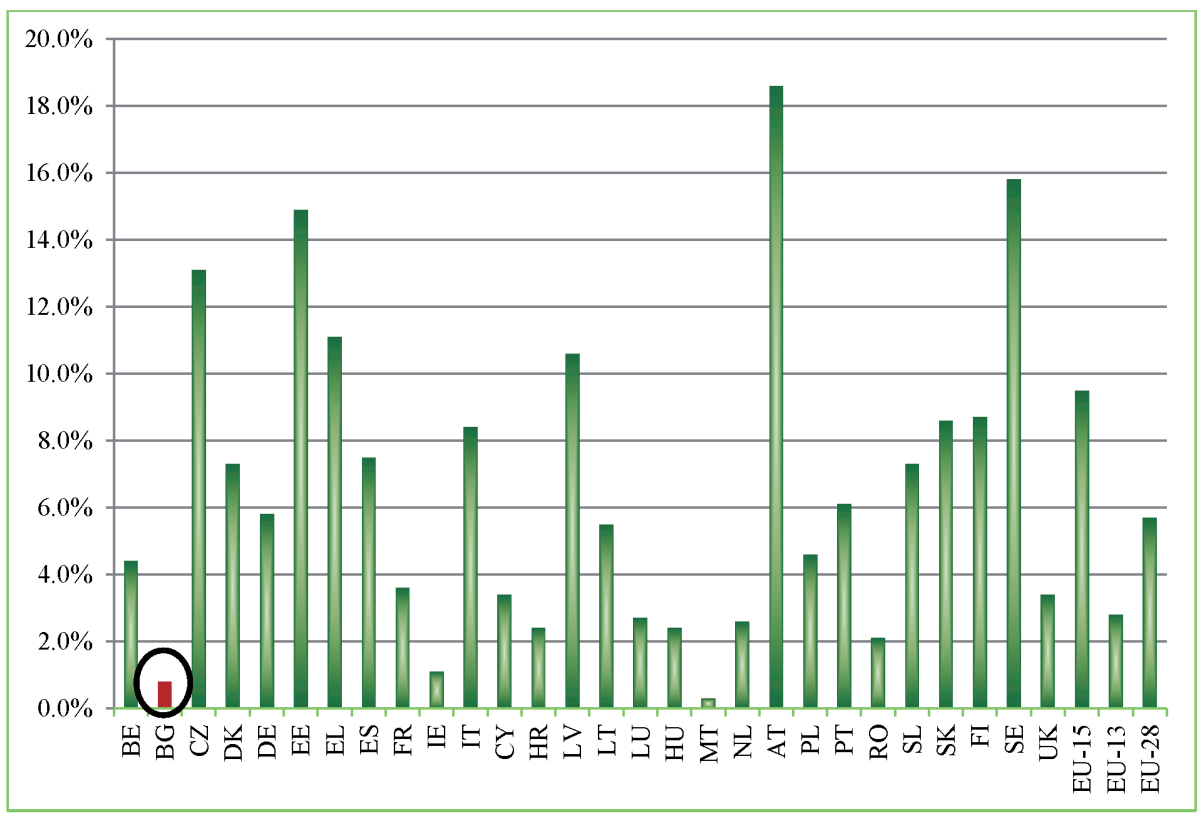

Fig. 3. Utilised agricultural area for organic agriculture (2012,\%).

Source: European Commission (2014).

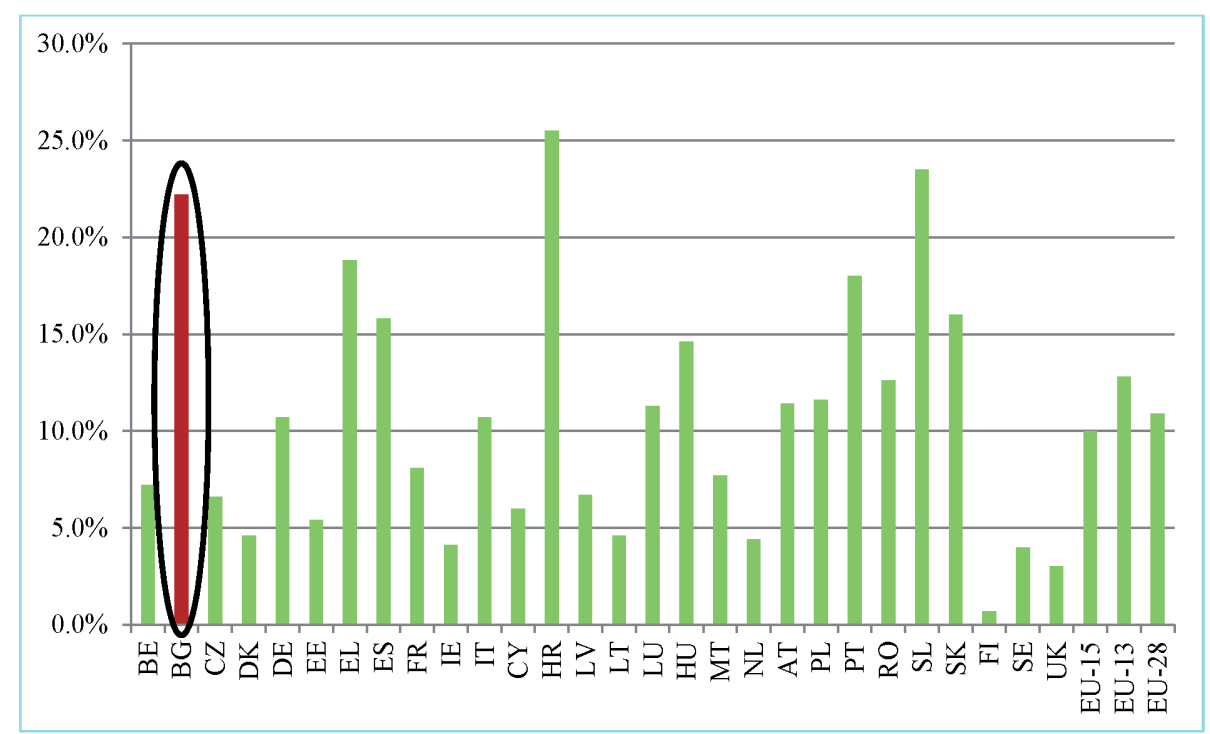

Fig. 4. Utilised agricultural area, classified within NATURA 2000 (2012,\%).

Source: European Commission (2014). 
European ecologic network NATURA 2000 is subject to special institutional protection of the European society. There is a solid consensus about this topic and increased budget for supporting farmers having lands in this network. The demand for production from areas under NATURA 2000 has risen, which is a guaranty of its purity. Opportunities to produce with closed production cycle increase the range of goods with opportunities to add value.

The support for pro-ecologic practices and farmers' management methods is innovative investment. One of its forms is a renovated "start-up", which has high degree of return in socio-economic aspect. Figure 5 expresses an opportunity for sustainable production, which fully complies with "restart" or "start-up". In the presence of large natural potential allowing for grazing livestock breeding, the institutional change has led to a complete sector marginalization. At almost one third of UAA covered by high-mountain grasslands and meadows, home of one of the rarest biotopes in Europe, paradoxically Bulgaria reports one of the lowest density indicators for livestock units per hectare (Figure 5).

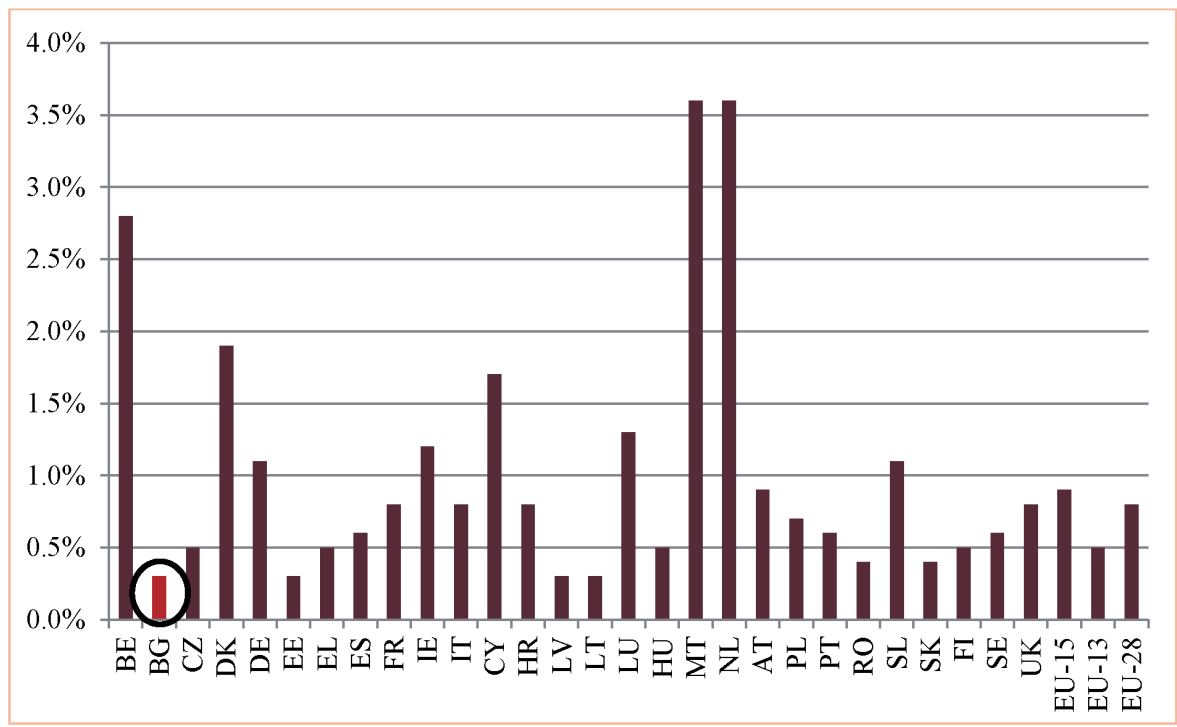

Fig. 5. Livestock density index (2010, livestock units/ha).

Source: European Commission (2014).

The graphical image of the information presented in Figure 5 gives grounds for a detailed analysis for the future. The low livestock density index is a focus for indepth analysis and for giving a receipt for resolving many problems of Bulgarian agriculture. These problems result from the institutional change, the natural restitution and the wrong logics of the conducted reform. This situation is a result of 
overlapping of the old institution, due to the transformation, and the new situation after the EU-27 accession. The problems are many, complex, multidirectional, partly solvable, and somewhat surmountable. Political will, professional expertise and actors having the above-mentioned qualities are necessary.

The village and agriculture sustainability was registered also in the field. Locally, there were people motivated to occupy fields with crop growing and livestock breeding, even without the EU support. Results from the two empirical and sociological studies testified to this: "Ecological culture of farmers", realized within the project "Transformation of the national value system and its synchronization with European models: development of ecological culture as an indicator for translation of European values in Bulgarian society" 2008-2012. That was a multidisciplinary research led by Prof. Dr. of sociological sciences Anna Mantarova from the Institute for Study of Societies and Knowledge at Bulgarian Academy of Sciences, realized with the financial support of the Fund for Scientific Research.

Every fourth respondent from the first empirical and sociological research led in 2010 in Blagoevgrad region, characterised by its small-scale production, declared its intention to enlarge its farming activity. That was the opinion of almost every seventh registered agricultural producer from the national empirical research from 2013. Those field results showed the positive attitude among Bulgarian villagers to continue the primary sector of production.

\section{Conclusions}

The presented analysis reveals sustainable practices, which result from the fact, that: "For centuries the agricultural production lies at the base of Bulgarian society building" (Hadziiski, 1974). This fact is determined by favourable natural conditions and unique agro-ecological conditions for agricultural production in Bulgaria, combined with definite socio-cultural traditions of Bulgarian rural residents. This represents the genesis of Bulgarian village sustainability. It is sustainable, but needs institutional change, consisting not only of controlling mechanism or a set of applied imperative rules. A favourable institutional framework, modelled by the active attitude of the state, will contribute to the important role of the natural factor for upgrading the existing institutional culture and overcoming of some development shortcomings of agriculture. The century-old preconditions of the village sustainability, combined with institutional direct and reverse links, could revive production structures in some regions and insure healthy products for Bulgarian consumers. 


\section{References}

Agrarnata kriza I kak da se izleze ot neia (1991). Sofia: BAN, p. 293.

European Commission (2014). CAP Context Indicators - 2014 update. December 2014.

Hadziiski, I. (1974). Bit i dushevnost na nashia narod. Sofia: Balgarski pisatel.

Iliev, I. (2004). Ikonomikata na Balgaria prez perioda 1949-2001. Sofia: PK D. Blagoev, p. 425 .

Kabakchieva, P. (2007). Dvulikiat Yanus: Evropeyski pravila v postkomunisticheska sreda. Sluchayat SAPARD. Sociologicheski problemi, 3-4, pp. 121-150.

Ministersvo na zemedelieto i hranite. Agrarni dokladi 2000-2015.

Nonchev, A. (2015). Novata ikinomicheska sociologia: teoretichni dostizenia i savremenni predizvikatelstva. Nauchni trudove na UNSS. 2015, vol. 2, pp. 19-55.

North, D. (2000). Institucii, institucionalna promiana i ikonomicheski rezultati. Sofia: LIK.

North, D. (2004). Pinosat na institucionalizma za pazbiraneto na ikonomikite v prehod. Lekcia iznesena prez 1997 g. Media Times Review. Fevruary: 1-2.

Pamukchiev, H. (1991). Kriza v agrarnite otnoshenia. Agrarnata kriza i kak da se izleze ot nea. Sofia: BAN.

Stankov, V. (1990). Problemi na sobstvenostta I na stopanisvaneto v selskoto stopanstvo. Ikonomicheska misal, no. 10, pp. 28-36.

Statisticheski godishnik na Balgaria. Sofia, Nacionalen statisticheski institut 2008-2015.

Stoyanov, Al. (2015). Sociologicheski analyz na ikonomicheskite neravenstva: problemi na metodologiata. Nauchni trudove na UNSS. vol. 2, pp. 281-323. 
PLAMENA YOVCHEVSKA

Akademia Rolnicza

Sofia

\title{
BUŁGARSKA WIEŚ - ZAGADNIENIE ZRÓWNOWAŻENIA W PROCESIE TRANSFORMACJI
}

\begin{abstract}
Abstrakt
Artykut stanowi próbe znalezienia odpowiedzi na pytania, które prawdopodobnie dobrze odzwierciedlaja sytuacje bułgarskiej wsi. Dlaczego istotne jest jej zrównoważenie, szczególnie często podkreślane w okresach transformacji? W czasie kryzysu wieś pełni role socjalnego buforu dla członków danej społeczności. Zrównoważenie wsi jest pokazane przy użyciu zestawu wskaźników.

Podstawytego zagadnienia tkwiąw trójelementowymłańcuchu: człowiek natura - społeczeństwo. Współcześnie etymologiczna definicja wsi, określajaca ja jako miejsce, gdzie mieszkańcy zajmuja się rolnictwem, musi ulec modyfikacji. W celu wykazania zrównoważenia wsi, w artykule omówiono znaczenie zmian w WPR i rozwiazaniach dotyczacych kwestii ekologii. Człowiek i jego otoczenie znajdują się wśród priorytetów XXI wieku.
\end{abstract}

Słowa kluczowe: wieś, zrównoważenie, transformacja, WPR 2014+.

Accepted for print: 20.06 .2017$.

Unless stated otherwise all the materials on the website are available under the Creative Commons Attribution 3.0 Poland license. Some rights reserved to the Institute of Agricultural and Food Economics - National Research Institute.

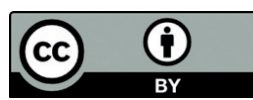

